\title{
Chapter 4 \\ Places and Spaces of the Others. A German Reception Centre in Public Discourse and Individual Perception
}

\author{
Daniel Göler
}

\subsection{An Outline of the Problem and Its Theoretical Embeddedness}

The refugee migration to Europe in 2015 and the political management of the socalled "refugee crisis", which is more and more perceived as a "European refugee reception crisis" (Knipper 2016: 993), have dominated daily public discourse since then. From a scholarly point of view, refugee mobility has produced both spatially and personally alienated human beings, as discussed by Rosa (2014: 122ff). Among the manifest outcomes are refugee camps as places without any history and identity, thus "non-places" (Augé 1992). According to anthropologist Marc Augé, nonplaces are one of the characteristics of "super-modernity" (1995: 30): "Something we perceive, but only in a partial and incoherent manner". These basic assumptions are fundamental to the subsequent analysis of refuge and asylum procedures at the local level in a receiving country. Therefore, a German reception and accommodation centre serves as an example. The main concern of analysis is exploring the geographical logic of social practices there (Werlen 2013: 84). Hence, this study focuses on the phenomenon's "geographicities" (Göler and Krišjāne 2017) and thereby on the wide range of the refugees' migration spatialities. The concept takes into account in particular that the (spatial) order of individuals, social groups, economies, relevant institutions and their interrelation is highly influenced by specific framing, settings and developments. This means that the notion of place and space is interpreted as a relational one. Against this background it is obvious that this study has to use a broad empirical approach in order to cover two relevant research interests. One is the spatial context of and the local discourse on such a reception centre, and the question of how these are produced in an arena of tensions between

D. Göler $(\bowtie)$

Institute of Geography, Migration and Transition Studies, Bamberg, Germany

e-mail: daniel.goeler@uni-bamberg.de

B. Glorius, J. Doomernik (eds.), Geographies of Asylum in Europe and the Role 
policies at the European, national and local levels. The other is the manner in which these processes of permanent negotiations constitute the camp's logic as a nonplace and what variations it is subject to.

The rationale of the analysis concentrates in particular on the spatial perception of migrants and asylum seekers. From this perspective, refugee camps and reception centres are transitory places where the residents as individuals are temporarily reduced to the functionality of the institution. Thus, such centres correspond strongly with Foucault's figure of heterotopia (1967): They are the spatial product of political will and governance, reflecting the constituting society and yet functioning according to their own rules. In this respect, a refugee reception centre (and every other kind of camp) represents an impersonal, ahistoric and identity-poor transit area in its given local context. Elements of "Liquid Surveillance" as described by Bauman and Lyon (2013) such as restricted access and entrance rituals underline the scrappy, fragmentary and incoherent perception of such a place in a local neighbourhood. Generally, little information about the site and the residents leaks to the outside. In this chapter, fresh material from three empirical studies on media discourse, individual perceptions and corresponding reflections will be presented. ${ }^{1}$

After a description of the methodology, concept and research questions and a concise discussion on refugee migration, asylum and encampment, interest will be turned to the "Reception and Accommodation Centre of Upper Franconia" in Bamberg, a medium-sized town in Northern Bavaria, Germany. In what follows, this institution is considered as a non-place and thus serves as a distinct example for the topic of places and spaces of the other. The main goal of the chapter is a further reflection on the "geographicities" of refuge in a local context.

\subsection{Methodology and Concept}

Unravelling such a complex institution like a refugee reception centre and related aspects requires a multidimensional approach. Consequently, the social-geographic study on the institution and its residents is based on a methodological triangulation. The main findings on the centre's geographicities are gathered from discrete empirical studies. Each one covered specific research questions and used separate survey methods adapted to the individual set of research problems.

The analysis of the media discourse related to the reception centre (Sect. 4.5) is a longitudinal approach from the very beginning to the stage of consolidation. It provides insights into public attitudes as well as local policies towards the reception

\footnotetext{
${ }^{1}$ The study is based on results of ongoing research on (refugee) migration, reception and return, conducted by the working group on Geographic Migration and Transition Studies (Prof. Dr. Daniel Göler) in cooperation with the european forum for migration studies (efms), Institute at the University of Bamberg. Bettina Fritzler, Jan Thelen and Mehdi Sejdiu contributed substantially to the empirical part on refugees and locality. Thanks are also due to the operator of the reception centre (Government of Upper Franconia), who agreed to fieldwork on site.
} 
centre. Related research questions focus mainly on relevant changes over time: are there any decisive incidents to identify what information is reported on the location and the residents, and how this communication is done? How is the functionality of the centre assessed? Therefore, media coverage was scrutinized in detail for the period 2015-2016. The source of information was the online archive "inFranken", where articles from leading Northern Bavarian newspapers published by the Media Group Upper Franconia (especially "Fränkischer Tag") are available. Text analysis concentrated on 312 articles, of which 189 were directly related to the camp.

As Sect. 4.5 represents the perspective from outside, these findings are contrasted in Sect. 4.6 by the views of the centre's residents. Insights were gathered through a total of 20 qualitative biographical interviews with occasionally, but not systematically selected residents ("snowball sample"). At the time of the survey in mid-2016, the vast majority of the residents (and hence the interviewees) were from Western Balkan countries, mostly Albania and Kosovo. The interviewees were between 17 and 56 years old. Interviews lasted up to an hour and were conducted on site in their native language. The main research questions and guidelines for the interviews and the talks about individual migration biographies were the motivations and circumstances of the migration "into asylum", the current personal situation in the centre and their perspectives if and when they were returned to their own countries. Guiding questions were: Did the migrants have any opportunity to gain resources in Germany for restarting their lives after deportation? What are their individual experiences of failed immigration to Germany or the Schengen area, respectively?

Then, attention is drawn to refugees' perception of the locality and surroundings (Sect. 4.7). The spatial representations of selected residents were surveyed by using the method of mental maps, because "human spatial behaviour is dependent on the individual's cognitive map of the spatial environment" (Downs and Stea 1973: 9). During narrative interviews, residents were asked to make a drawing of the spatial environment where people live and stay ("sketch map") ${ }^{2}$. In the second half of 2017 , a total of 15 tested persons documented their spatial perception, which is determined by spaces and places relevant to them. The interest was in how the residents at their stage of transit deal with this status from a spatial perspective. How do they cope with their specific situation and which spatial patterns exist, or do they tend to be randomized?

As the empirical findings give broad information on the geographicities of refugee mobility, detailed synthesis and generalization is necessary. Thus, the discussion at the end concentrates on dichotomies, variabilities and limitations inside and outside the examined non-place.

\footnotetext{
${ }^{2}$ The method, its application in geography, and relevant studies go back to the 1960s and 1970s. In the context of a cognitive turn in geography, individual behaviour and spatial perception became the focus of interest (see Lynch 1960; Horton and Reynolds 1971; Downs and Stea 1973).
} 


\subsection{A New Analytical Perspective}

The "refugee crisis" of 2015 soon found its expression in academic literature. Analysis of the challenge that Europe faced in those days focused on the admission of some hundreds of thousands of asylum seekers. Another issue was the valuation of cultures of welcome and assistance; an example is Schiffauer et al. (2017), including a contribution on Bamberg (Rauber 2017: 232). Sometimes fundamentalist and ideology-driven political criticism, partially charged by emotions (see contributions in Hess et al. 2017), draws attention away from the scarce analysis of spatialities of refugee migration, asylum and reception (such as Ramadan 2012). Literature beyond a couple of studies on the Western European receiving countries in general and Germany in particular often deals with specifics such as the airport asylum procedure (Nieswand 2018) or the role of borders or boundary drawings (“b/ordering"; Hartmann 2017: 239). Only a few emphasize refugees' everyday life and the local practice of housing (e.g. Kublitz 2016).

This may distract scholars from the fact that immigration, refuge and asylum are not new, but periodically recurring topics. Without going too far back into German history, there are parallels to the situation in the 1990s with regard to asylum migration at that time and to the admission of refugees from Yugoslav secession wars. As a result, the entire complex of asylum procedures or paradigms of integration have been thoroughly questioned (cf. Isaakyan 2016: 169ff).

This leads directly to the challenge of securitization of refugees and the fields of encampment and self-settlement. Self-settlement means that "the refugees make their own choice about where they reside and the state's role can vary enormously“, whereas encampment "refers to a policy which requires refugees to live in a designated area set aside for the exclusive use of refugees "(Bakewell 2014: 129). The first variant is seen as being more efficient, but in a humanitarian sense hardly justifiable if we take into account the critical situation of an increasing number of migrants in the Global South. It is the large number of refugees that legitimizes the variant of organized encampment in the regions of origin or neighbouring countries there.

Encampment is still mostly thought of from the perspective of the Global South. Collyer (2014: 118ff), for example, implicitly locates the "Geographies of Forced Migration" there. Indeed, the vast majority of studies on refugee camps analyze the situation in and around contexts of refuge and scrutinize the situation in camps in Jordan, Lebanon or Darfur (see for example: Ramadan 2012; Minca 2015; Oesch 2017). Thus, scholars have recently expressed regret that "the focus of research is geographically divided between South and North" (Rechitsky 2016: 172). However, an explicit transfer of analysis on encampment or camp settings to the Global North is rather an exception.

That is somewhat surprising given that refugee reception is anything but new in Germany, for example going back to the post-Second World War period when so called "border crossing camps" were established (Oltmer 2016: 50). Until today, institutions like that exist in quite similar forms, though renamed as a "collective 
camp for foreigners" ("Sammellager für Ausländer") and, more recently, as a "reception centre for asylum seekers" ("Zentrale Aufnahmeeinrichtung für Asylbewerber"). The concept of centralized accommodation of asylum seekers is, as part of the ongoing political debate on asylum, recently celebrating a re-birth (more on which later on). This seems to be tricky because in a historically sensitized country such as Germany, encampment is highly contentious politically, socially, morally and academically (Pieper 2010). Nevertheless, "hotspots" and "transfer zones" for asylum seekers who are trying to reach Fortress Europe are again part of serious considerations; that is, extra-territorialization of the problem in the form of "offshore processing" (Papagianni 2016: 326) accompanied by accelerated discussions on efficient and, at the same time, humanitarian practice according to international law.

A central part of these discussions was the implementation of arrival and deportation facilities as they were being set up in Bavaria in 2015, at least as another "way of grounding geopolitics in the everyday" (Ramadan 2012: 65). On the top of the "refugee crisis", this raised the question of the adequate form of accommodation for asylum seekers in Germany. To sum up, all these focal points are further indicators for broadening the perspective and "to look at the relationship of migration [from] within the Global South to power dynamics within the Global North" (Rechitsky 2016: 173).

However, the centralization of reception procedures and decision-making are becoming the general rule of admission practice in Germany, since so-called "AnKER-Zentren" were an integral part of the national government's Coalition Agreement in February 2018. ${ }^{3}$ Since then, eight such centres have been established nationwide. The blueprint for this form of onshore processing has existed in Germany for 3 years: the reception and accommodation centre AEO (Aufnahmeeinrichtung $\boldsymbol{O}$ berfranken) that opened in Bamberg in 2015 (known as

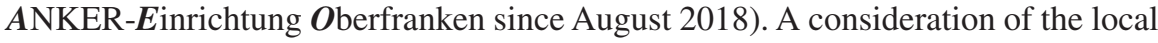
effects, hence geographicities, of migration, refuge and asylum is worthwhile in this example, since the Bamberg institution represents the future standard of admission and asylum practice in Germany and possibly throughout Europe.

\subsection{Non-place AEO?}

\subsubsection{Facts About the Centre}

According to the above - the (academic) interpretation of reception and accommodation centres as non-places and future (political) models for asylum processing Bamberg's AEO may even be considered as a laboratory for finding efficient ways

\footnotetext{
3"Arrival, decision, and resettlement or deportation should take place in AnKER centres" (Koalitionsvertrag 2018, 107). The acronym AnKER - which is reminiscent of "anchor" - comes from the German spelling: Ankunft, $\boldsymbol{E}$ ntscheidung, kommunale Verteilung bzw. Rückführung.
} 


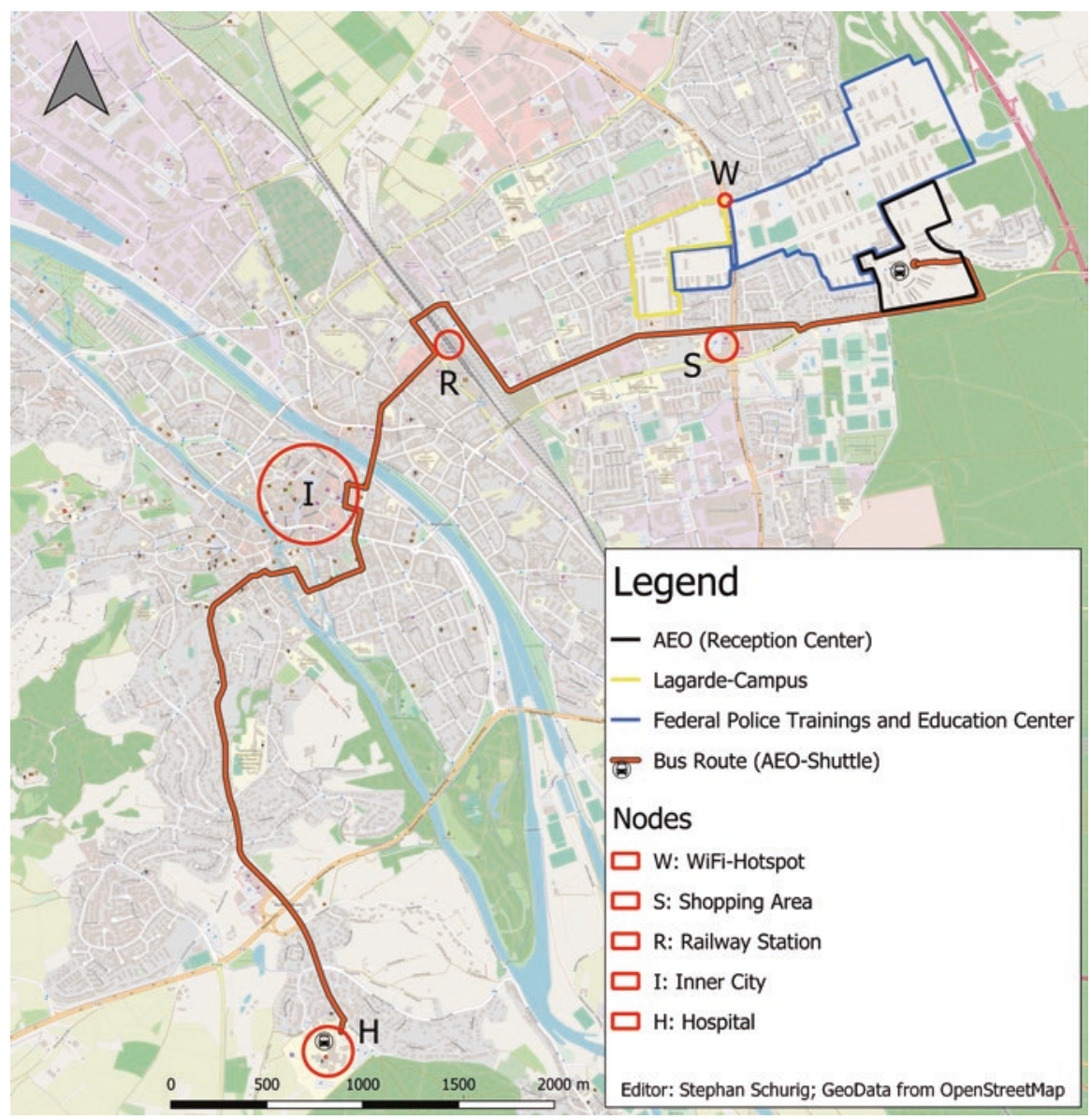

Fig. 4.1 Plan overview of AEO and its location in Bamberg

to implement asylum legislation. The facility opened on 14 September 2015 as one of two "admission and deportation centres" (ARE) in the Federal State of Bavaria. ${ }^{4}$ There was a very short lead time as former military sites were available. In Bamberg, this was a 190-hectare housing area inside the former US barracks (Fig. 4.1). After the final withdrawal of the US forces in 2014, a long-term urban conversion process should have started. Given the dramatic situation in mid-2015 and the urgent question of housing for a large number of migrants, the transformation into accommodation for asylum seekers was obvious. As the premises were owned by the Federal Republic of Germany and not the municipality of Bamberg, national authorities could easily leave this area in a top-down decision by contract to the Federal State

\footnotetext{
4 “Ankunfts- und Rückführungseinrichtung", abbreviated to ARE II. The other one, ARE I, is in Manching/Upper Bavaria.
} 
of Bavaria to install a reception centre there, essentially without the consent of the Bamberg municipality.

ARE II opened exclusively as a special reception centre for asylum seekers from safe countries of origin such as the Western Balkan countries. Since July 2016 a regular reception centre for asylum seekers has been integrated into the complex, and a third pillar came in September 2017 in the form of an arrival centre. Since then the camp has been renamed AEO. All relevant authorities such as the federal agency for migration and refugees (BAMF), state immigration authority, youth welfare office and an application office of the administrative court are present on site. This guarantees that the procedure for granting the right of asylum according to the law is conducted accurately, but in an accelerated manner. Asylum seekers should receive information on whether they are allowed to stay in Germany or whether they must return to their country of origin as soon as possible. The average length of stay is 2 months, according to the Government of Upper Franconia who operates the centre. $^{5}$

The initial capacity of 1500 residents steadily expanded. In July 2017, the (current) final expansion to 3400 beds was reached. It has been reported that there is now capacity for 4500 residents, but such a level of occupancy has never been reached. Usually, the number of residents varies between 1200 and 1600. In early March 2018, for example, almost 1300 people were living there, including 223 in the special reception centre and 1073 in the regular reception centre. At the beginning (2015-2016), most of the centre's residents came from Western Balkan countries. Hence, the centre is popularly known as the "Balkan Centre" ("Balkanzentrum"), although nowadays the origins of the residents is much more diverse and includes migrants from north Africa, Syria or former Soviet republics such as Russia, Ukraine and Georgia.

The life span of the reception centre is a crucial question. According to contracts between the Bamberg municipality and Bavaria, it is limited to 10 years. However, after the recent developments in refugee politics in Germany, this seems to be wishful thinking in Bamberg: Why should a well-functioning and highly efficient prototype, built up with enormous efforts, be shut down and then be substituted by capacity constructed elsewhere? Therefore, at the latest in 2025, Bamberg will prove the litmus test regarding political commitments by the federal and state governments towards local politics.

\footnotetext{
${ }^{5}$ As of 2 March 2018. Information about the centre and details concerning current occupancy can be found on the government's website: https://www.regierung.oberfranken.bayern.de/buerger_ und_staat/migranten/ae_oberfranken/index.php
} 


\subsubsection{Asylum Policy and the Camp's Political Framing}

After the reform of the German asylum legislation in the 1990s, asylum seekers were usually accommodated decentrally. Housing was provided in apartments or small collective units on the social or private housing market. This was common practice in Bavaria and thus in Bamberg. Three factors determined the need for a reaction and policy response in 2014-2015: the increase in refugee immigration, a massive shortage on the housing market, and the need to enhance efficiency in operating asylum procedures. As a consequence, gradual adjustments to immigration laws and the extensive constriction of asylum regulations and their application have been implemented on the basis of two acts: The Asylum Packages I and II (Asylpaket I und II) of October 2015 and February 2016, respectively. Among the concrete measures therein are the special reception and accommodation centres. Beside the more or less informal suspension of Dublin regulations, the identification of "safe countries of origin" is a focal point regarding the new regulation. The latter include (in addition to the member states of the EU) the Western Balkan countries (since 2014-2015) and Senegal and Ghana (since 1993). The extension of the policy to the Maghreb countries is planned. Asylum seekers from these countries are directed to reception centres immediately after arrival and application, similar to the procedures in Bamberg. Thus, a group of migrants with a low probability of gaining asylum is constructed ex ante; in the case of asylum seekers from Albania and Kosovo for example, the quota for successful application in 2015 was $0.2 \%$ and $0.4 \%$, respectively (BAMF 2016, p. 50). Applicants are then obliged to live in the reception centres, which provide accommodation and further subsistence until the federal office's decision is made. During this period of time, they are not allowed to work or to leave the county where they have been allocated to. If their application for asylum is rejected as "manifestly unfounded" or even "inadmissible", these regulations apply until they leave Germany.

Another basic element of the new regulations on asylum is the changeover from the monetary to the in-kind principle, which means that beside accommodation, food and all other basic needs are provided by the state. Monetary benefits are thus reduced to a minimum and even drop completely if the application is rejected. So-called "misguided incentives" should be avoided. This seems to be the case - or at least is implied - for a certain number of migrants from Southeast and East European countries, who generate, by immigration into the German asylum system, an income above the average in their home countries.

The accelerated asylum procedures apply analogously to migrants from countries with a "high probability of approval". These are countries with a protection rate of at least $50 \%$ (currently Eritrea, Iraq, Iran, Syria and Somalia). In fact, the reforms outlined were crucial for administrative coping with the rapid rise in the number of asylum seekers, including registration, application and processing in such a short period of time. Thus, the intended increase in efficiency in operational terms is achieved, as long as the rejected asylum seekers do not make appeals. The 
same applies to the goal of clarifying the residence status as a prerequisite for subsequent integration measures or access to the labour market.

Regarding that interrelation, Etzold (2017: 82) argues "that the two fields - the 'field of asylum' and the 'field of labour' - were purposely kept separate from another. This interrelation was recently reconfigured in complex ways and is still dominated by restrictive regulations concerning the asylum procedures". Vice versa, with this approach any kind of integration during the asylum procedure should be kept to a minimum, not least in order to simplify measures of deportation if the application is rejected.

\subsubsection{Criticisms of the AEO}

The Bamberg reception and accommodation centre earned much recognition, especially from conservative government policy in Bavaria and beyond. But there was and still is a lot of criticism concerning the reception procedures in detail or making asylum regulations stricter in general. The latter concerns in particular the weakening of the fundamental right of asylum by constructing groups of refugees with a low vs. high probability of remaining and the related categorization in advance, solely on the basis of origin. However, this point is not specific to AEOs and does not need to be further elaborated upon in this chapter.

Directly related to the location is criticism of its martial form. Not at least with the massive fencing dating from the days of the US Army, the physiognomy of the site actually conveys the impression of imprisoning and thus interning refugees. In fact, residents are allowed to leave and enter the area at any time; the operator points out safety reasons for the residents regarding fencing. However, unauthorized access, i.e. non-residents without a permit, is denied. Corresponding entrance controls and checkpoints underline permanent surveillance and the character of a nonplace (Fig. 4.2). Although it is in the direct vicinity of bourgeois residential areas, it is, due to limited accessibility, at the same time far away. It comes as an anachronism that the situation today evokes the era of the US barracks.

Other criticism is directed to questions of individual housing, integration of residents and schooling of children. All these points are subject to individual as well as ideological evaluations, as will be elaborated upon in the analysis of public media discourse. 


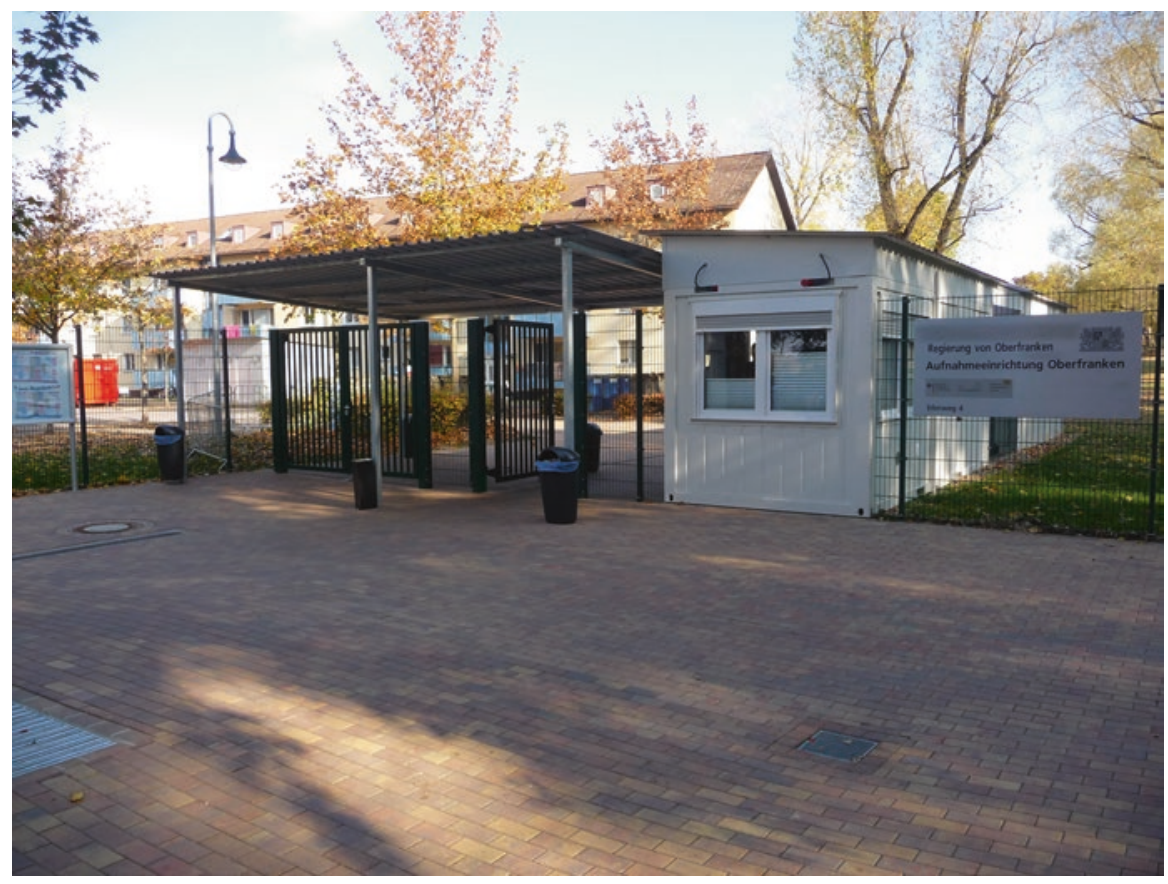

Fig. 4.2 Checkpoint and entrance control at Bamberg's AEO; in the background one of the residential buildings. (Photo by author, 21 Oct. 2018)

\subsection{The AEO in Public Media Discourse}

\subsubsection{The Location}

In 2015 and 2016, the media coverage of Bamberg's AEO focused on three topics: the location and its relation to the housing market, the residents of the centre, and the functionality of the (non-)place.

The decision of the former military area as a suitable location was initially judged as an advantage. At the time, there was even talk of a "tailwind for conversion" (Thelen 2017: 42ff.). However, no one is talking about this any more, especially since a Federal Police training centre was also opened on the conversion area in 2016, and only a small crumb remains of the original idea of urban development. Moreover, in the meantime the process of urban conversion has started in the smaller area of the historic Lagarde barracks (see Fig. 4.1), not least because of compensations from the Federal State of Bavaria. The release of the area occupied by the AEO in 2025 is, as already indicated, at least questionable.

Another persistent strand of discourse is around the demand for affordable housing. This is the main concern of a citizens' initiative called "Army site in citizen hands", established in 2014. They want to provide moderate-priced housing in the 
former garrison. ${ }^{6}$ In fact, the situation on the regional housing market has worsened considerably with the opening of the AEO and the police camp. Thereby, the real estate market has received much less space through the conversion process than expected. At the same time demand has increased considerably, not least due to several 100 employees in both institutions. The price level for housing in Bamberg-a medium-sized town in a rural area—is already comparable with metropolitan areas. But it is not only the competing institutional use that makes the demand for a rapid conversion of the residential buildings in the former barracks irrelevant. The "uniform functional buildings" with attributes like "compact and heated" (Thelen 2017: 44) may be appropriate for short-term use and temporary accommodation, but without extensive and lengthy renovation and modernization they would have little attraction for the real estate market. Incidentally, critics overlook the question of ownership in this regard: The acquisition of the site from the federal state at regular market conditions and the subsequent project development of the whole area would hardly be affordable for the municipality of Bamberg in the foreseeable future anyway. In this respect, the topic of location implicitly leads back to the focal question of ownership of the former military area and the resulting discourse about the acceptable capacity of the camp.

\subsubsection{The Residents}

The discourse concerning the residents was initially indeed determined by questions of scale. In particular after the incidents on New Year's Eve 2015 in Cologne, when hundreds of women were sexually assaulted by (mostly) male, young North African and Arab migrants and numerous thefts were recorded, a critical atmosphere developed with regard to origin, "otherness" and masculinities of migration. At the end of 2015, it seemed that the ARE and its residents - a limited (and declining) number of migrants from Western Balkan countries - were more or less accepted among Bamberg's citizens, but then came media reports of a conversion to a regular reception centre, where migrants from (North) African sending countries would be accommodated. After initial problems the "Balkanzentrum" seemed to be broadly accepted, not least because it was occupied by "white Europeans". But now, the centre would turn into a facility with people from culturally much more distant origins. This strongly evoked the arguments of the thesis of hierarchical otherness of immigrants, which would - with the UK as an example - ultimately lead to the suppression of the autochthonous (or as such perceived) majority population of "white Britains" (Coleman 2006). The claim that the character of the centre as a "place of lack of perspective" (Thelen 2017: 48) would pass, since asylum seekers with better perspectives would live there, remained largely unheard. Rumours and reports of rising crime in the form of shoplifting, car break-ins, damage of property

${ }^{6}$ Details on the initiative can be found on their Facebook account [www.facebook.com/ BIArmyGelaende/, last visit 13 March 2018]. 
and bodily injury in and around the reception centre did not make things better. Again and again, media reported on certain groups of nationalities for different reasons and far too often these were criminal acts. However, it becomes evident that the image of the centre's residents, produced by the media, is exposed to constant change (Thelen 2017: 59).

\subsubsection{The Functionality}

The functionality of the (non-)place is defined by the concentrated presence of the relevant authorities, the proximity to the applicants and the aim of accelerating the procedures, including redistribution or repatriation, depending on the decision. This was pointed out in surprising openness with the initial naming as ARE (an abbreviation for arrival and deportation). AEO, in contrast, sounds at least more openended, even though the dominance of the function as a "special reception centre" indicates deportation as the most likely outcome. Moreover, new terms such as "turbo deportation centre", "deportation camp", "Bamberg deportation facility" or "deportation camp without integration" mushroomed in the course of 2016 (Thelen 2017: 61ff.).

The organization and execution of deportations, which usually take place in the early morning and apparently give residents not much more than 10 min to prepare, is highly controversial. Even the role of the non-lockable doors to and inside the apartments is discussed distinctively in this regard. On the one hand, they facilitate a deportation if residents oppose. On the other hand, the government points out safety reasons for the residents in case of fire or any other incident and their responsibility as operator. Other controversies are about the medical service, schooling or a bus shuttle set up in March 2016. The latter connects the AEO with the main railway station, the central bus station and the hospital. On the one hand, the incremental improvements regarding the functionality of the institution are appreciated. On the other, a discussion simultaneously emerged in the public discourse, because all of these improvements for refugees are always evaluated in competition with public services offered to Bamberg's citizens. Thus, the shuttle bus was immediately classified as a luxury for free, although the regional government of Upper Franconia had already withheld a small part of the residents' "pocket money" in advance.

Concerning the functionality of the whole facility, the discourse always spins around two opposing perspectives: One emphasizes the efficiency of the centre, mainly with regard to the previously constructed group of asylum applicants with a "low probability" of their claim being accepted. The other declares the institution as completely inhuman, despising basic human rights and subordinated to the political desire to temporarily isolate the residents. 


\subsection{The Reception Centre as a Place of Transit? The Residents' Perspective}

The ever-changing occupancy, and hence the character of the AEO as a place of transit, makes it difficult to generate coherent findings on the perspective of the residents. In fact, given the heterogeneity of individual cases and the biographies of asylum seekers, there can be no such coherence. At the time of our survey (JulyAugust 2016), the sample implicitly focused on a slightly more homogenous group, as during the centre's first year, the residents were predominantly migrants from Western Balkan countries. The majority of the interviewees had already lived in (decentralized) accommodation all over Northern Bavaria, sometimes for a longer period of time. They saw themselves on a good path of integration through school attendance and regular work. Then they had to move to the ARE in Bamberg, in order to accelerate further processing. Almost all of them had had a negative decision on their application before, but had not yet been deported due to various issues such as missing documents or ongoing medical problems. This explains in a certain number of cases the disproportionately long stay in the reception centre. Those asylum seekers whose applications had been unproblematic in the bureaucratic sense, or those who recognized the futility of an asylum application in their case and stopped the procedure on their own, had already left the ARE by the time of the survey. As a consequence the sample predominantly represented a group of people whose asylum procedures had been problematic (in terms of asylum procedures). This also explains that all of our interviewees stayed much longer in the camp than the average duration of 2 months mentioned above.

For these migrants, the stay in Bamberg was often just another stage in a multifaceted migration trajectory. They are bound in an "elusive migration system" (Göler and Krisjane 2016: 2017), like those migrants from Kosovo and Albania, who act in a highly flexible, spontaneous and unpredictable way. Two biographies underline this. Firstly there was a 38 -year-old Albanian citizen (I12) ${ }^{7}$, born in Tepelena, who had lived and worked in Greece for 11 years. Due to the economic crisis there he returned to Albania in 2011. In 2015, he decided to leave to Germany "into asylum" with his family (a wife and three children). Secondly there was a 31-year-old Kosovan from Prishtina (I6) who came to Germany in 2011 and experienced slightly different conditions with liberal regulations at that time. He worked in a restaurant, then in horticulture and attended a language course. His work permit was no longer renewed from the end of 2015, and so since April 2016 he had been living in Bamberg's reception centre after living in three intermediate decentralized accommodation facilities in Northern Bavaria.

In other cases, too, the impression emerges that for migrants from Western Balkan countries who came to Germany before 2015, the prospects of staying were not bad at first (at least in the form of an exceptional leave to remain, i.e. the imposition of a ban on deportation according to $\$ 60$ of the Residence Act). I hypothesize

${ }^{7}$ The interviews are rendered using anonymized codes based on the survey order (I1-I20). 
that those migrants were indirectly affected by the "refugee crisis". This seemed to be the case for a 28-year-old Kosovan from Gjakova (I19), who - after having spent parts of his childhood in Saarbrücken - had lived with his family in several small towns in Upper Franconia since 2014. He had worked in a fast-food restaurant for 9 months, where he was recently offered vocational training. The notice of rejection had been received 3 months previously. He had had to stop working and to cancel his apprenticeship. Since his family is obliged to leave the country, but cannot cover the travel expenses to do so, they will be deported. That will mean a ban on entry and residence in the Schengen area for the next years.

For all of our interviewees, return is not a realistic option to solve individual problems and will not be a permanent solution (see also Göler and Doka 2015; Göler 2015). All statements given by the interviewees on their plans after return point to repeated emigration - to other countries or even back to Germany, but then not in the migration channel of asylum. The tragic misunderstanding of that time, i.e. the rumours that political asylum also applied to migrants from Western Balkan countries, seems to be dispelled. Most migrants admit in a remarkably open way that wrong information, given by family members, a far too blue-eyed migration decision, or, especially in the case of Kosovans, false promises from human smugglers led to a misguided migration project.

Some of the statements indicate that there are still deficits of information. The view that "if you work here, if you are informed and integrated, then you have the right to live here" (I6) may be understandable from an individual perspective, but it does not lead to a residence permit being granted. I5 constructs a completely bizarre definition of political asylum: "I applied for political asylum because I am disappointed with the politics in Kosovo." Similarly, the expectation "I was sure that I would get asylum, because France is now dominated by the non-white race and I read that Germany wants to avoid that through the immigration of white, Albanian migrants" (I18) is wholly misguided. This indicates again that evidently wrong expectations have arisen and that erroneous knowledge or crude interpretations are still circulating.

Coming back to the situation of residents in the AEO, their separation from the surrounding environment, the lack of any kind of social embeddedness and restricted access to the labour market are manifest problems. Conscious of the limitations to their stay, migrants seek to aggregate resources and capital for the period after their expected deportation, but have only very few opportunities to do so. When transferred to Bamberg, some migrants were deprived of the networks needed for such (possibly informal) employment. This, in turn, limits the scope for action in the case of return, due to a lack of social and financial resources. A few admit that they earned some money from illegal employment which is reported to be worth 50 EUR a day (I1). In addition, at best, it is possible to earn something through (approved) ancillary activities in the camp. Due to changes in social assistance provision - from direct allowances to benefits in kind - generating savings in that way is very difficult. Only I18, who lived outside his home country for the first time 20 years ago and looked back on a remarkable migration biography, stated that he had saved enough from emigration to live in Kosovo in the future, if necessary. 
A study on ensuring children's rights in reception and accommodation centres (Alexandropoulou et al. 2016) assesses the situation of the residents and in particular the Roma population as critical. First, the authors refer to deficits in schooling (ibd.: 19ff. $)^{8}$. A place in the regular schools in Bamberg is indeed not provided, but rather a substitute in the form of a special educational institution is offered on site. School attendance is barely controlled and absence is not sanctioned. Second, with regard to fears of already traumatized children, having non-lockable doors in apartments is considered highly problematic. Third, discrimination and antiziganism, which is common all over the Balkans, is prevalent in the AEO as well. All in all, respondents to the study's survey consider the living conditions of families there to be "consistently negative" (ibd.: 27).

Conversely, in our survey on accommodation in the centre, beside a couple of unsurprising negative facts, some positive ones were mentioned as well. These include the good healthcare system in Germany in general, notably the medical care offered on site, and the respectful handling by the authorities. Residents seem not to be used to this when it comes to authorities in their country of origin: "I have more rights here than in Kosovo, even though I am an asylum seeker" (I1). Nevertheless, the situation of Roma, an ethnic group that is undoubtedly threatened all over Southeastern Europe and whose situation is precarious in the AEO, too, seems dramatic. On the one hand, deportation is not an option due to a bundle of uncertainties "at home". As a consequence, Roma families try to resist their return by all means. However, as they are obliged to leave, they have no access to bare subsistence. Beyond mere accommodation, they have no means of livelihood even in the reception centre. For this reason, I2 openly states that he is more or less forced to steal goods for his family's survival.

Beyond all assessments of the situation in the centre - which, as shown, strongly depends on the perspective - living there is a life in permanent limbo with manifold uncertainties, no matter if somebody has a high or low probability of staying. Regardless of the length of the asylum procedure and the related stay in the centre, or even the perspective of staying or leaving the country, the AEO is - in the words of Augé (1992) - a footloose, anonymous (non-)place of transit. In this respect, the following sequence analyzes to what extent daily life in such a parallel world - a heterotopia - is reflected in the perception and use of space by the residents.

\footnotetext{
${ }^{8}$ This study was funded by the Hildegard Lagrenne Foundation and focuses exclusively, in accordance with the foundation's mission, on the education, inclusion and participation of Sinti and Roma.
} 


\subsection{Coping with Locality: The Resident's Spatial Perception of the Local Area}

Spatial perception, knowledge and behaviour of the centre's residents are determined by the marginality and isolation of the location on the one hand and by individual, biographically conditioned capabilities on the other. The corresponding survey by means of "mental maps" was calculated with the heterogeneity of the sample in advance. The 15 participants in the experiment had mixed nationalities (Syria, Eritrea, Iran and Morocco $)^{9}$, and they differed in gender (ten males and five females), length of stay ( 2 weeks to 8 months) and level of education. Concerning academic and school education a distinction was made between "high" (five people with university degrees, mainly from Syria and Iran), "medium" (qualifying school leaving certificates, four people) and "low" access to education (six Eritreans; Fritzler 2018). As expected, the depth of the spatial knowledge correlated strongly with the level of education, and a higher age led to more extended spatial knowledge. In contrast, factors such as duration of stay or language skills had hardly any differentiating influence. The 15 sketch maps differed considerably: the number of spatial elements included in the drawings, for example, varied between six and more than 120. Generally, sketches are analyzed by number, type, naming, location and, if applicable, description of spatial elements.

In detail, six of the maps made by the Eritrean migrants mentioned above represent the image of local- or neighbourhood-focused individuals showing a very limited range of action (Fig. 4.3). Their drawings contain a manageable number of elements (between 6 and 16) that are predominantly in the immediate vicinity of the reception centre. A prominent strategic point is a busy intersection on a ring road not far from the AEO. There is a Wi-Fi hotspot with free access, which is the only urban quality in that location. The main hub in the closer town centre is an internet cafe, which provides high-speed internet access and offers pre-paid cards at reasonable prices. The shop is operated by a Nigerian migrant ("the najeryamen", Fig. 4.3), which makes it worth a visit as well. Besides that, further spatial knowledge of these residents is rather poor. For three of them, an A4 sheet was more than sufficient for the whole drawing.

Four other participants in the survey, coming from Syria, Iran and Morocco and with a moderate level of education, have more extended spatial knowledge, albeit mainly centred on the AEO and its neighbourhood. They included significantly more spatial elements in their maps and show higher variance (17 up to 70 elements). These elements, their location and the topographic and physiognomic relations are often incorrectly reproduced. Individual perception is usually influenced by individual interests or needs. For example, in the case of a Christian Iranian

\footnotetext{
${ }^{9}$ It is the survey period, a year later, which explains the different structure of the samples, most obviously regarding nationalities. This evidences the high turnover and variability of the institution.
} 


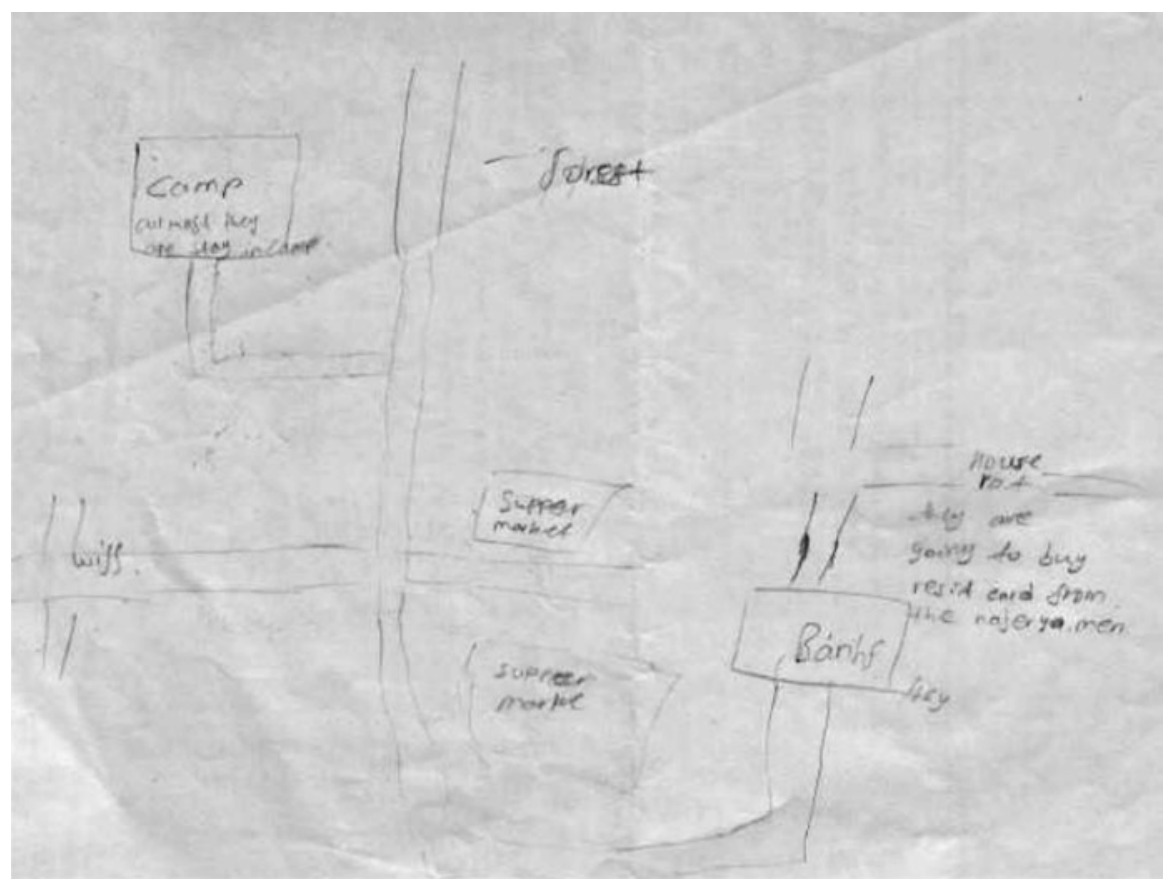

Fig. 4.3 Sketch map by a young migrant from Eritrea with limited spatial information. (Fritzler 2018, 77)

woman, churches play an important role (Fig. 4.4). In addition, shopping sites in Bamberg's central pedestrian zone are mentioned. What is on offer there is perceived, but cannot be benefited from due to individual, mostly financial, restrictions. A 35-year-old male Syrian drew a wide range of actions and numerous facilities, whose name and function he hardly knew. It revealed that he rides his bicycle through Bamberg and collects returnable bottles in order to earn a little bit of money. This also explains why he is quite familiar with Bamberg's vibrant bar area, even though he never visits any of the pubs - be it because he doesn't want to or because he cannot afford to. He serves as another example of obviously widespread capability constraints among asylum seekers.

Five other, highly educated refugees from Syria and Iran have very detailed knowledge of space - one of the sketch maps includes more than 120 elements. They show a clear orientation of the town centre. There is broad information on places of various functions, such as social services like Caritas, a dentist, a pharmacy, a lawyer, the town hall, shops, etc. Furthermore, several institutions for leisure and culture such as a cinema or a temporary art installation in public space are included, as well as symbolic places, such as the so-called "Gabelmann", which is a well-known meeting place in the main pedestrian zone. In two of these maps, the $\mathrm{AEO}$ and its surrounding neighbourhood are not included. Interestingly, the shuttle bus, which has connected the AEO with the railway station and the hospital since 


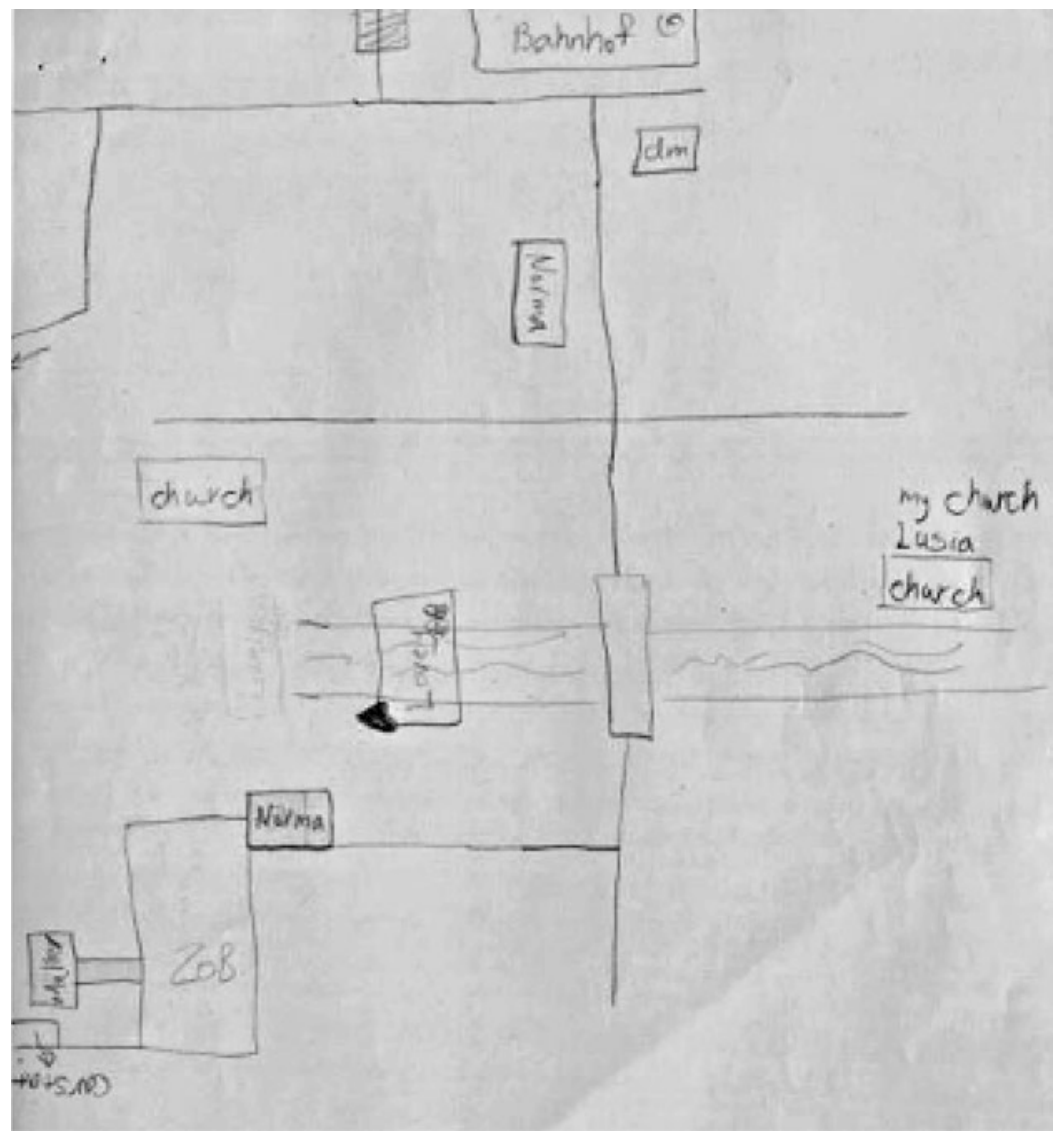

Fig. 4.4 Sketch map by a Protestant Iranian woman with accurate spatial information of the town centre. (Fritzler 2018, 71)

March 2017, plays an important role in the orientation and spatial behaviour of the residents (Fig. 4.5): In one case, the entire drawing was calibrated along the bus route, which was reproduced in great detail. Another respondent reported to have previously done the paths on foot and was thus limited when buying daily goods. So, infrastructure like a bus connection could be a means of planning, regulation and control of the residents' spatial pattern at the same time.

All in all, the residents' spatial field of action is a result of necessities of everyday life and individual interest outside the camp, sometimes combined with specific personal needs. The educational level plays a determining role, capability constraints a limiting one and provisions that are free of charge - like mobility via a shuttle bus - may have a liberating but also controlling effect. As a summary of the sketch maps of the AEO residents, a spatial pattern in the form of an east-west axis appears. This is of course due to the location of the AEO on the eastern outskirts of the town and the important function and orientation points located to the 


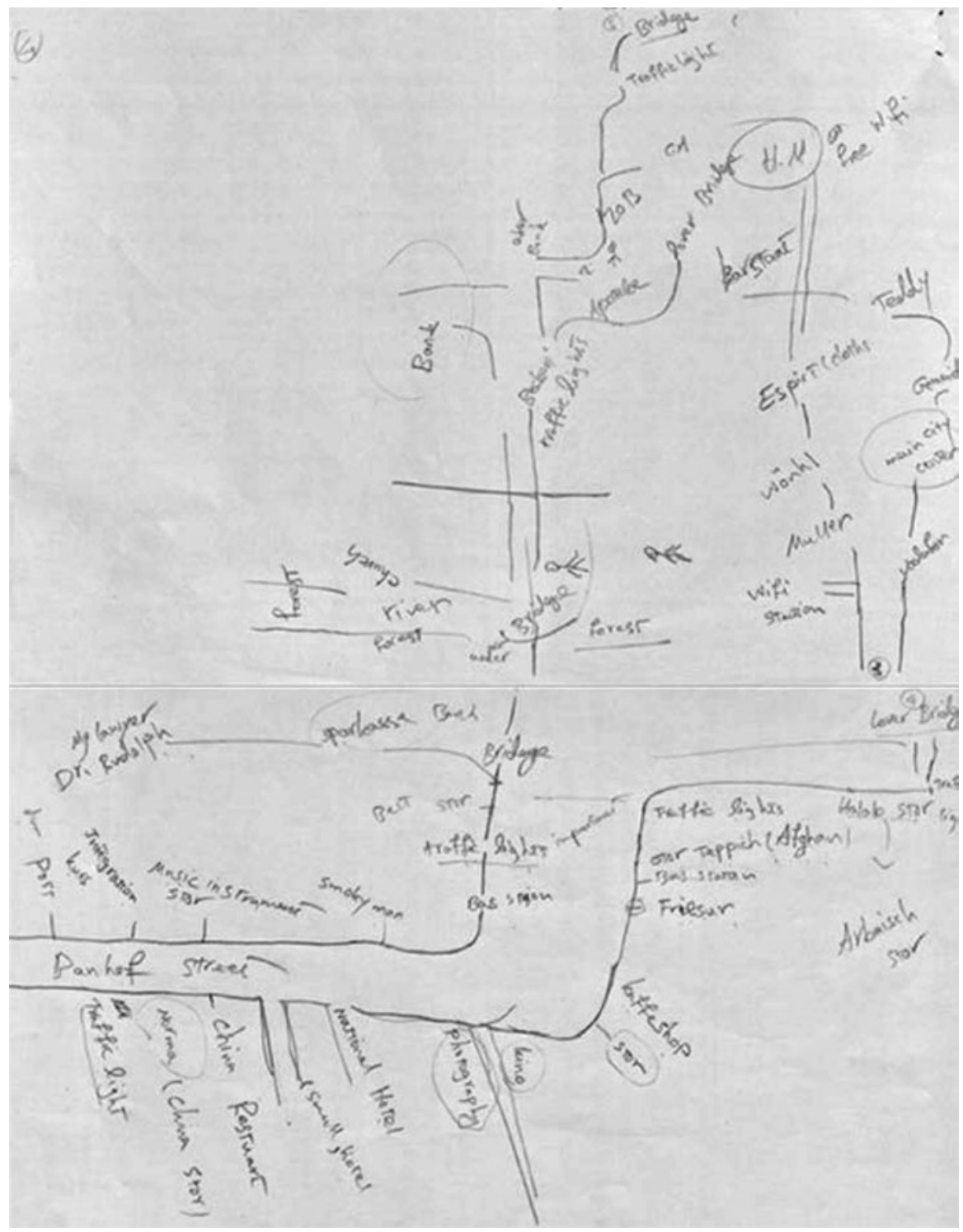

Fig. 4.5 Section of the sketch map by a woman from Iran with detailed information along the bus route and on the town centre. (Fritzler 2018, 65)

west of it towards the inner urban area. Places north or south of this axis, with the exception of the mentioned intersection, remain excluded. Incidentally, the findings from the analysis of mental maps presented here are essentially identical with those of perception geographies and research on action space in general (Downs and Stea 1973). 


\subsection{Discussion and Results}

The geographicity of the reception centre is, as has become clear, characterized by manifold dichotomies, variabilities and limitations. This affects both the location, including the camp's spatial embeddedness, and the residents. This specific constellation of multiple ambiguities seems to be inherent to such places (see Oesch 2017). Following Martin (2015), although in a completely different context, this phenomenon may be interpreted as a "CampScape", with the suffix -scape representing the camp's generally fluid character and referring in particular to the special setting of the place (Martin 2015: 14).

The interplay of space, place and individuals defines the very special assemblage of Bamberg's CampScape, which includes certain dichotomies. This includes in temporary terms the fact that the duration of stay in the centre is unpredictable, but generally limited. Asylum seekers' transitory episodes end in compliance with the politically formulated function of the centre, i.e. the result of staying (and further integrating) or leaving the country. In this regard, the question of origin is more than significant. It defines, via the political construct of safe (and unsafe) countries of origin, the likelihood of staying and thus legitimizes almost ex ante the subsequent decision for approval of a residence status or upcoming deportation as a further dichotomy. The problem is defined by requirements of high efficiency of government institutions on the one hand, and preservation of humanity, human rights and international agreements on refugee treatment on the other. This question is of course irrelevant for the centre as a non-place, because this kind of dichotomy is reduced to an average as described by Augé (1995). Regardless of the motivation of migration, all residents have the same de jure status during their stay in the camp until the final decision on the asylum procedure has been made.

In fact, the occupancy was not homogenous either structurally or over time, but characterized by manifold variabilities of the CampScape. Time, for example, was a decisive factor in my field studies. It has been shown that the resident structure could change fundamentally just within half a year in terms of origin, ethnic group and/or citizenship due to the fluid character of the camp. In the Bamberg centre, for example, migrants from safe countries of origin in the Western Balkans were replaced by refugees from countries affected by civil war and other crises. This intensive fluctuation of 300-500 entrances and exits per month is the trigger for the structural variability regarding the composition of the residents. It was also part of the massive initial-and ongoing-discussion on the maximum capacity of the institution and related scepticism of many of Bamberg's citizens: On the one hand there is an informal consensus on a tolerable number of 1500 residents, and on the other hand capacity is officially still stated as 3400 . There is no doubt that in case of a renewed increase in refugee immigration this capacity will be reached soon. Even an increase to the gloomy 4500 is relatively easy to implement if necessary.

The residents are subject to various limitations. For the duration of the asylum procedure, living in the camp is compulsory and residence obligations prevail. Selfsettlement of refugees was and is not an option in Germany. Even local freedom of 
movement is limited by the fencing off of the area. However, this is an essential part of the safety guarantee for the camp, thus making it acceptable to most local residents. Even the residents and their habitus are characterized by limitations and constraints. This was demonstrated, for example, in terms of spatial orientation and interest in the local area, including the individual's abilities. This is offset by certain disillusions, possibly resulting in immobility for some residents. But for most of them, even simple needs like a shuttle bus or the random availability of Wi-Fi access may change spatial patterns, which indicates that the CampScape and its people are organized elusively. These are the hallmarks of a certain alienation of refugees in the local and urban context, in which (politically deliberate) approaches to integration are largely missing. In addition, limitations also come into play when multiple capability constraints become relevant and they certainly do not end when it simply comes to shopping or going to a pub.

\subsection{Conclusion and Outlook}

Housing in the "Laboratory AEO" and the CampScape in Bamberg (as an intraterritorial solution to refugee immigration) or, for example, a refugee camp in Jordan (as an extraterritorial solution from a European point of view), are modest responses to the global challenge of migration. Each answer brings with it its own specific differentiation, dichotomy and limitation, which may serve as a superordinate finding of the study of refuge in the local context. With regard to the realities of refugee migration, any kind of average might not exist anyway. But the non-place can be produced whenever and wherever, if necessary - Bamberg's AEO serves to prove that argument.

Encampment, most recently in the form of AnKER centres, is a way towards efficient asylum processing in Germany. The figure of heterotopia, super-modernity and the vision of non-places each provide adequate access for an analysis of places and spaces like that. The concept of non-places (Augé 1995) is without any doubt the most suitable framework for a study of encampment in a narrow sense. As the (non-)place is just one part of the bigger picture, the suggestion is to widen the conceptual and theoretical lens. As underlined by the broad empirical approach applied, a more holistic assessment involves an analysis of the whole range of relevant phenomena in and around non-places like a reception centre, including their manifold interrelations. The relational perspective in terms of geographicities offers the chance to analyse spatialities, people and institutions on different scales and with multidimensional methodologies. There are lots of elements that produce the logic of the place, thus the heterotopia of the AEO, such as personal attitudes, perceptions, individual perspectives and origins, legal issues, politics, public discourse and, not least, time. The logic of the place is the product of both the organizational framing and the institutional setting. 


\section{References}

Alexandropoulou, M., Leucht, C., \& Salimovska, S. (2016). Gewährleistung der Kinderrechte in den Aufnahme- und Rückführungseinrichtungen für Asylbewerber mit geringer Bleibeperspektive. Berlin: Hildegard Lagrenne Stiftung.

Augé, M. (1992). Non-lieux: Introduction à une anthropologie de la surmodernité. Paris: Seuil.

Augé, M. (1995). Non-places. Introduction to an anthropology of Supermodernity. London/New York: Verso.

Bakewell, O. (2014). Encampment and self-settlement. In E. Fiddian-Qasmiyeh, G. Loescher, K. Long, \& N. Sigona (Eds.), The Oxford handbook of refugee and forced migration studies (pp. 127-138). Oxford: University Press.

BAMF Bundesamt für Migration und Flüchtlinge. (2016). Das Bundesamt in Zahlen 2015. Nürnberg: Asyl, Migration und Integration. English edition: Federal Office for Migration and Refugees (2016). Migration, integration, asylum - policy report 2015. Nuremberg.

Bauman, Z., \& Lyon, D. (2013). Liquid surveillance: A conversation. Cambridge: Polity Press.

Coleman, D. (2006). Immigration and ethnic change in low-fertility countries: A third demographic transition. Population and Development Review, 32(3), 401-446.

Collyer, M. (2014). Geographies of forced migration. In E. Fiddian-Qasmiyeh, G. Loescher, K. Long, \& N. Sigona (Eds.), The oxford handbook of refugee and forced migration studies (pp. 112-123). Oxford: University Press.

Downs, R. M., \& Stea, D. (1973). Image and environment. Cognitive mapping and spatial behavior. Chicago: Transaction Publishers.

Etzold, B. (2017). Capitalising on asylum - The reconfiguration of refugees' access to local fields of labour in Germany. Refugee Review, 3, 82-102.

Foucault, M. (1967). Andere Räume. In K. Barck, P. Gente, H. Paris, \& S. Richter (Eds.), Aisthesis. Wahrnehmung heute oder Perspektiven einer anderen Ästhetik (pp. 34-46). Leipzig: Reclam.

Fritzler, B. (2018). Aktionsräume von Asylbewerbern in Bamberg: Eine sketchmap-basierte Analyse. Unpublished master thesis in Social- and Population Geography, Faculty for Humanities, University of Bamberg.

Göler, D. (2015). Der Westbalkan als Quell- und Transitraum von Fluchtmigration: Quo vaditis? Südosteuropa-Mitteilungen, 55(6), 6-19.

Göler, D., \& Doka, D. (2015). ReEMigration in Albanien - Von der Emigration zur Remigration und vice versa? Südosteuropa-Mitteilungen, 55(1), 22-31.

Göler, D., \& Krišjāne, Z. (2016). Elusive migration systems. Shifting from transnationalism to transregionalism. In J. Dominguez-Mujica (Ed.), Global change and human mobility (pp. 25-36). Singapore: Springer.

Göler, D., \& Krišjāne, Z. (2017). Geographicities of migration. Adding a new direction. The Region, 305, 13-15.

Hartmann, M. (2017). Contested boundaries: Refugee centers as spaces of the political. Zeitschrift für Flüchtlingsforschung, 1(2), 218-243.

Hess, S., Kasparek, B., Kron, S., Rodatz, M., Schwertl, M., \& Sontowski, S. (Eds.). (2017). Der lange sommer der migration. Grenzregime III. Berlin: Assoziation A.

Horton, F. E., \& Reynolds, D. R. (1971). Effects of urban spatial structure on individual behaviour. Economic Geography, 47(1), 36-48.

Isaakyan, I. (2016). Integration paradigms in Europe and North America. In A. Triandafyllidou (Ed.), Routledge handbook of immigration and refugee studies (pp. 169-179). New York: Routledge.

Knipper, M. (2016). Migration, public health and human rights. International Journal for Public Health, 61, 993-994. https://doi.org/10.1007/s00038-016-0893-x.

Koalitionsvertrag zwischen CDU, CSU und SPD. (2018). Ein neuer Aufbruch für Europa. Eine neue Dynamik für Deutschland. Ein neuer Zusammenhalt für unser Land. Berlin: [Coalition Agreement of the German Federal Government 2018]. 
Kublitz, A. (2016). The ongoing catastrophe: Erosion of life in the Danish camps. Journal of Refugee Studies, 29(2), 229-249. https://doi.org/10.1093/jrs/fev019.

Lynch, K. (1960). The image of the city. Cambridge, MA: The M.I.T. Press.

Martin, D. (2015). From spaces of exception to 'campscapes': Palestinian refugee camps and informal settlements in Beirut. Political Geography, 44, 9-18. https://doi.org/10.1016/j. polgeo.2014.08.001.

Minca, C. (2015). Geographies of the camp. Political Geography, 49, 74-83.

Nieswand, B. (2018). Die Transitzone und die Fiktion der Nichteinreise. Das Flughafenasylverfahren im Zwielicht von Normalität und Ausnahme. In J. Oltmer (Ed.), Migrationsregime vor Ort und lokales Aushandeln von Migration (pp. 345-376). Wiesbaden: Springer VS.

Oesch, L. (2017). The refugee camp as a space of multiple ambiguities and subjectivities. Political Geography, 60, 110-120.

Oltmer, J. (2016). Migration vom 19. bis zum 21. Jahrhundert (Enzyklopädie deutscher Geschichte 86). Oldenburg: De Gruyter.

Papagianni, G. (2016). Asylum in the twenty-first century: Trends and challenges. In A. Triandafyllidou (Ed.), Routledge handbook of immigration and refugee studies (pp. 320329). New York: Routledge.

Pieper, T. (2010). Das lager als variables instrument der migrationskontrolle. In S. Hess \& B. Kasparek (Eds.), Grenzregime. Diskurse, Praktiken, Institutionen in Europa (pp. 219-228). Berlin/Hamburg: Assoziation A.

Ramadan, A. (2012). Spatialising the refugee camp. Transactions of the Institute of British Geographers, 38(1), 65-77. https://doi.org/10.1111/j.1475-5661.2012.00509.x.

Rauber, M. (2017). Freund statt fremd e.V. In W. Schiffauer, A. Eilert, \& M. Rudloff (Eds.), So schaffen wir das - eine Zivilgesellschaft im Aufbruch: 90 wegweisende Projekte mit Geflüchteten (pp. 232-234). Bielefeld: Transcript.

Rechitsky, R. (2016). Global migration and extraterritorial controls: The case of international refugee policy in Ukraine. International Journal of Sociology, 46, 169-188. https://doi.org/10.108 0/00207659.2016.1163990.

Rosa, H. (2014). Beschleunigung und Entfremdung (4th ed.). Berlin: Suhrkamp.

Schiffauer, W., Eilert, A., \& Rudloff, M. (Eds.). (2017). So schaffen wir das - eine Zivilgesellschaft im Aufbruch: 90 wegweisende Projekte mit Geflüchteten. Bielefeld: Transcript.

Thelen, J. (2017). Der Ort der,Anderen'. Die Rolle lokaler Medien bei der Entstehung von Nicht-Orten. Unpublished master thesis in Social- and Population Geography, Faculty for Humanities, University of Bamberg.

Werlen, B. (2013). Praktiken der Welt-Bindung. Gesellschaftliche Raumverhältnisse als transdisziplinäres Forschungsfeld. Europa Regional, 21, 2013(2015), 1-2, 83-92.

Open Access This chapter is licensed under the terms of the Creative Commons Attribution 4.0 International License (http://creativecommons.org/licenses/by/4.0/), which permits use, sharing, adaptation, distribution and reproduction in any medium or format, as long as you give appropriate credit to the original author(s) and the source, provide a link to the Creative Commons license and indicate if changes were made.

The images or other third party material in this chapter are included in the chapter's Creative Commons license, unless indicated otherwise in a credit line to the material. If material is not included in the chapter's Creative Commons license and your intended use is not permitted by statutory regulation or exceeds the permitted use, you will need to obtain permission directly from the copyright holder.

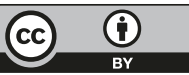

